\title{
Water transfer during rehydration of micellar casein powders
}

\author{
Pierre SCHUCK $^{\mathrm{a} *}$, Serge MEJEAN ${ }^{\mathrm{a}}$, Anne DOLIVET ${ }^{\mathrm{a}}$, Claire GAIANI ${ }^{\mathrm{b}}$, \\ Sylvie BANON ${ }^{\mathrm{b}}$, Joël SCHER ${ }^{\mathrm{b}}$, Romain JEANTET ${ }^{\mathrm{a}}$ \\ a UMR1253, Science et Technologie du Lait et de l'Euf, INRA-Agrocampus Rennes, \\ 65 rue de Saint-Brieuc, 35042 Rennes Cedex, France \\ ${ }^{\text {b }}$ LSGA, Laboratoire de Science et Génie Alimentaires, 2 avenue de la Forêt de Haye, B.P. 172, \\ 54505 Vandœuvre-lès-Nancy Cedex, France
}

\begin{abstract}
Rehydration is an essential quality attribute of a dairy powder, as most powders are dissolved before use. However, there can be problems associated with the different stages of the rehydration process: i.e. wettability, sinkability, dispersibility and solubility. Many sensors and analytical methods such as the insolubility index, NMR spectroscopy, turbidity, viscosity and particle size distribution can be used to study water transfer in dairy protein concentrates during rehydration. Micellar casein (MC) powder, obtained by tangential membrane microfiltration of milk followed by spray-drying, is an interesting dairy powder due to its high protein content, and it is a valuable model of milk micelles. However, enrichment of milk in micellar casein decreases water transfer during rehydration of MC powder. The slow water transfer during MC powder rehydration is timeconsuming. Some studies have shown that insolubility is related to a decrease in the water transfer during rehydration and not to thermal denaturation. Other studies have also shown that the decrease in water transfer might be related to the micellar structure. In the present study, the destructuration of micelle induced by addition of phosphate or citrate solution to MC increased water transfer during rehydration. Water transfer in the dairy protein concentrate during rehydration was found to be related to the aqueous environment, the nature of the mineral salts, the structure of the dairy proteins, the size of the powder particle and the rehydration conditions.
\end{abstract}

\section{micellar casein / powder / rehydration / wettability / dispersibility / solubility}

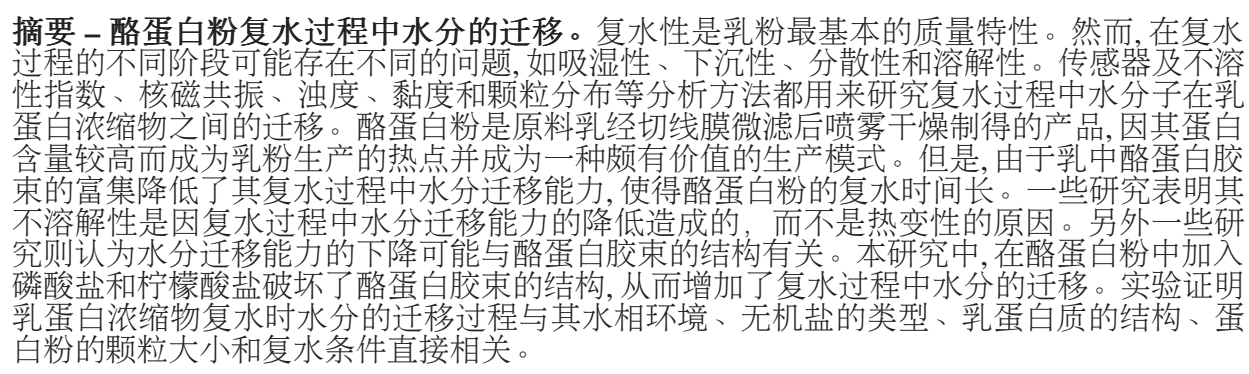

酪蛋白胶束 / 乳粉 / 复水 / 可湿性 / 分散性 / 溶解性

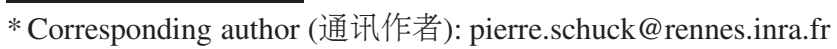


Résumé - Transfert d'eau au cours de la réhydratation de poudres de caséine micellaire. La réhydratation est un facteur déterminant essentiel de la qualité d'une poudre laitière puisque la plupart des poudres doivent être dissoutes avant utilisation. Des problèmes peuvent apparaître au cours des différentes étapes du procédé de réhydratation, i.e. : aptitude au mouillage/mouillabilité, aptitude au coulage/coulabilité, dispersibilité et solubilité. De nombreux moyens de détection et méthodes d'analyse, comme l'indice d'insolubilité, la spectroscopie RMN, la turbidité, la viscosité, la distribution des tailles de particules, peuvent être utilisés pour étudier le transfert d'eau dans les concentrés de protéines laitières au cours de la réhydratation. La poudre de caséine micellaire $(\mathrm{CM})$, obtenue par microfiltration du lait suivie de séchage par atomisation, est une poudre laitière intéressante du fait de sa teneur élevée en protéine, et un modèle valable des micelles du lait. Cependant, l'enrichissement du lait en CM diminue le transfert d'eau au cours de la réhydratation de la poudre de CM. La lenteur du transfert d'eau augmente le temps de réhydratation de la poudre de CM. Quelques études ont montré que l'insolubilité était liée à une diminution du transfert d'eau pendant la réhydratation et non à une dénaturation thermique. D'autres études ont aussi montré que la diminution du transfert d'eau pouvait être due à la structure micellaire. Dans la présente étude, nous avons montré que la destructuration de la micelle par ajout d'une solution de phosphate ou citrate à la CM augmentait le transfert d'eau pendant la réhydratation et que le transfert d'eau dans le concentré de protéines laitières était dépendant de l'hygroscopicité, de la nature des sels minéraux, de la structure des protéines laitières, de la taille des particules de poudre et des conditions de réhydratation.

\section{poudre / caséine / micelle / réhydratation / transfert d'eau / solubilité}

\section{INTRODUCTION}

Developments in membrane microfiltration processing of skim milk have made possible the preparation of micellar casein (MC) $[6,16]$. MC has excellent rennetcoagulating properties, as coagulation time and gel firmness are, respectively, reduced and enhanced compared with that of raw milk [16]. MC is an appealing material due to its high protein content and has been seen as a relevant model of native milk micelles $[5,11]$.

More and more food ingredients similar to MC are being produced as dehydrated powders obtained by spray-drying or freeze-drying to reduce transport costs and greatly improve their preservation. Rapid and complete reconstitution of these dehydrated products in water is essential for practical use [4]. Dissolution is an essential quality attribute of a dairy powder as a food ingredient [14]. Certain common difficulties are related to dissolution, which depends on different steps, i.e. wettability (ability to absorb water), sinkability (ability to sink into water), dispersibility (ability to disperse in single particles throughout the water) and solubility (ability to dissolve in water) [8]. The dissolution properties of dairy powders have been fully investigated by some authors but the dissolution process of MC has been less frequently studied $[1,7,10,18,21]$. Water transfer during rehydration of $\mathrm{MC}$ is low in comparison with water transfer of "low heat" milk powder [19]. The apparently high insolubility index (ISI $>14 \mathrm{~mL}$ ) of freshly dried MC powders [13], determined according to the IDF standard [12], does not result from insoluble material formed during spray-drying [20] or storage but from decreased water transfer in pure micellar casein compared with the water transfer of "low heat" milk powder (ISI < $0.5 \mathrm{~mL}$ ) during rehydration $[19,22]$.

The aim of this study was to investigate the rehydration mechanisms for MC powder, in order to improve the acceptability of this powder in the food industry.

\section{INSOLUBILITY INDEX}

The insolubility index (ISI, in \%) described by the IDF standard [12] for skim milk is the volume of sediment (for $50 \mathrm{~mL}$ ) after rehydration (10 $\mathrm{g}$ of powder 
Table I. Reconstitution period, insolubility index and rehydration time of dairy protein powders.

\begin{tabular}{|c|c|c|c|c|}
\hline Powders & $\begin{array}{l}\text { Size of particle before } \\
\text { rehydration }(\mu \mathrm{m})\end{array}$ & $\begin{array}{c}\text { RP using } \\
\text { NMR (min) }\end{array}$ & $\begin{array}{l}\text { ISI using IDF } \\
\text { Standard }(\mathrm{mL})\end{array}$ & $\begin{array}{l}\text { RT by using viscosity, } \\
\text { turbidity and particle } \\
\text { size profiles (min) }\end{array}$ \\
\hline$\overline{\mathrm{MC} \mathrm{G}}$ & 285 & 22 & 14.5 & 807 \\
\hline $\mathrm{MC} \mathrm{NG}$ & 47 & 8 & 3.5 & 571 \\
\hline $\mathrm{MC}+$ & 248 & 18 & 5.0 & 116 \\
\hline \multicolumn{5}{|l|}{ Carbohydrates } \\
\hline MC + WPI & 275 & 13 & $<0.5$ & 106 \\
\hline $\mathrm{MC}+\mathrm{NaCl}$ & 178 & 1 & 9.5 & $\mathrm{~nm}$ \\
\hline $\mathrm{MC}+\mathrm{CaCl}_{2}$ & 185 & $\infty$ & 14.5 & $\mathrm{~nm}$ \\
\hline MC + Phosphate/ & 176 & $6 / 5$ & $<0.5$ & $\mathrm{~nm}$ \\
\hline \multicolumn{5}{|l|}{ Citrate } \\
\hline WPI G & 244 & 5 & $<0.5$ & 4 \\
\hline WPI NG & 44 & 15 & $<0.5$ & 16 \\
\hline
\end{tabular}

$\mathrm{MC}=$ micellar casein $; \mathrm{G}=$ granulate $; \mathrm{NG}=$ non-granulate $; \mathrm{WPI}=$ whey protein isolate $\mathrm{RP}=$ reconstitution period; ISI $=$ insolubility index; $\mathrm{RT}=$ rehydration time; $\mathrm{nm}=$ not measured; $\infty=$ infinite delay.

in $100 \mathrm{~mL}$ of distilled water, at $25^{\circ} \mathrm{C}$ ), mixing (for $90 \mathrm{~s}$, at $4000 \mathrm{rpm}$ ) and centrifugation (for $300 \mathrm{~s}$, at $160 \times g$ ). The main factor controlling the ISI is particle temperature during the first stage from the initial moisture content down to below $10 \%$. It has been suggested that the most critical phase of first-stage drying corresponds to powder moisture lying in-between 20 and $10 \%$, when the critical factor is the powder temperature. Thus, facing ISI problems, attention must be given to all factors that increase the viscosity, droplet and particle size and outlet and inlet air temperature [17]. Methods to reduce the ISI include reducing the pasteurization effect, increasing the feed temperature by concentrated heating during concentration, avoiding long concentrate holding times before spray-drying, reducing the protein content by adding lactose, reducing homogenization to the lowest possible level, reducing the total solid content of the feed, applying higher atomization pressure using nozzles or higher speeds with atomizer wheels and reducing the inlet and outlet air temperatures [17].

However, in these studies, these effects are only measurable on skim or whole milk powders. The ISI of micellar casein (MC) powder is $>14 \mathrm{~mL}$ [19] (Tab. I), but this high value is not due to insoluble materials but only to a decrease in water transfer during rehydration. Increasing the agitation time to $900 \mathrm{~s}$, the temperature to $60^{\circ} \mathrm{C}$ and the agitation speed to $10000 \mathrm{rpm}$ or reducing the casein content considerably reduces the ISI (to $<2 \mathrm{~mL}$ ), showing that this is an artefact ISI. We have therefore developed new methods to describe the rehydration behavior of micellar casein by using NMR spectroscopy, turbidimetry, viscosimetry and granulometry.

\section{NMR SPECTROSCOPY}

We describe here a kinetic pulsed NMR technique for determining the rate of solution, the time required for complete reconstitution of powders and the transverse 
relaxation rate of reconstituted solutions. The method is presented for the reconstitution of both unenriched MC and MC enriched with soluble whey proteins, suitable carbohydrates or salts, and is potentially suitable for many food and non-food powders [4].

A 40-mm diameter glass tube filled with $20 \mathrm{~mL}$ of water at $40^{\circ} \mathrm{C}$ was put into the gap of the magnet of a Minispec Bruker PC 10 NMR spectrometer operating at the resonance frequency of $10 \mathrm{MHz}$. A suitably designed funnel and an electric stirrer (glass spatula) were inserted into the tube. The method was first described by Davenel et al. [3]: they showed that the solubilization rate was independent of the quantity of powder poured, up to $20 \mathrm{~g}$ powder $/ 100 \mathrm{~mL}$ water, and increased with the stirring rate. In subsequent experiments, the stirrer was adjusted after starting at a $1150 \mathrm{rpm}$ rotating rate for spray-dried powders, and $1 \mathrm{~g}$ of powder was poured into the water. NMR measurements were generally continued until the solution was completely reconstituted, except if insoluble materials were formed. Each decay curve was obtained by sampling a maximum of 845 spin echoes of a Carr-Purcell-Meiboom-Gill (CPMG) sequence every $20 \mathrm{~s}$ during the reconstitution period. Interpulse spacing between $180^{\circ}$ pulses was fixed at $2 \mathrm{~ms}$ to limit the effect of diffusion caused by stirring. The NMR kinetic method was used in triplicate. The CPMG curves were well approximated by the sum of two exponential curves of the form:

$$
\mathrm{S}(\mathrm{t})=A \mathrm{p} \exp \left(-\mathrm{t} \cdot \mathrm{R}_{2} \mathrm{p}\right)+\mathrm{As} \exp \left(-\mathrm{t} \cdot \mathrm{R}_{2} \mathrm{~s}\right)
$$

where Ap and $\mathrm{R}_{2} \mathrm{p}$ are the number of protons (\% of total proton population) and the relaxation rate of a fast decay component attributed to water protons in fast exchange with exchangeable protons of nondissolved powder particles, respectively, and $A s$ and $R_{2} s$ the number of protons and the relaxation rate of a slow decay component attributed to water protons and exchangeable protons in the reconstituted phase [3].

MC powders with a high ISI (14.4 mL) are generally considered to be poorly soluble powders in which rehydration of the micelle remains incomplete [13]. The present NMR method showed that reconstitution was in fact fully achieved after a long Reconstitution Period (RP), after which the Ap proton population was no longer observable: the RP was about $22 \mathrm{~min}$ for spray-dried MC powders. The NMR method showed that the addition of suitable macromolecules such as whey protein or carbohydrate before drying led to a significant improvement in the solubilization rate, the RP being reduced to $13 \mathrm{~min}$ and $18 \mathrm{~min}$ when $12 \%$ whey proteins and $12 \%$ carbohydrate were added, respectively (Tab. I). The decrease in the relaxation rate was mainly explained by the decrease in the MC concentration and by the increase in hygroscopic molecule content. Addition of $\mathrm{NaCl}$ to the $\mathrm{MC}$ concentrate before spray-drying considerably reduced the ISI and RP values (ISI $0.9 \mathrm{~mL}$; RP $9.5 \mathrm{~min}$ ) (Tab. I). In spite of this significant improvement in the reconstitution rate and slight solubilization of the micellar calcium, the relaxation rate $\left(\mathrm{R}_{2} \mathrm{~s}\right)$ of the reconstituted solution in the presence of $\mathrm{NaCl}$ was not significantly different from the pure MC relaxation rate. It has been hypothesized that $\mathrm{NaCl}$ should exert little influence on micelle structure [15] and that the signifiant decrease in the RP value is more probably related to the hygroscopic strength of $\mathrm{NaCl}$.

The addition of sodium citrate solution (SCS) or sodium phosphate solution (SPS) resulted in fast solubilization, as shown by the very low RP value and by the ISI value lower than $0.5 \mathrm{~mL}$ (Tab. I). The resulting solution consisted of casein micelles in the form of sodium caseinates, associated with the occurrence of a single proton population, characterized by NMR 
relaxation rates which were much lower than the relaxation rate measured with reconstituted MC. This could be attributed to a decrease in the amount of hydration water induced by the change in micelle structure. The transparency of the solution indicated the formation of soluble caseins related to greater quantities of calcium complexes.

Reconstitution of MC powder in the presence of $\mathrm{CaCl}_{2}$ salt led to considerable changes in protein structure, associated with instability of the casein micelles which began to precipitate just after mixing, as shown by the high ISI and the non-measurable RP value due to experimental delay. Moreover, the mathematical adjustment of the NMR relaxation decay signals measured with and without mixing revealed two NMR relaxation components. In the case of continuous mixing, the two relaxation rates corresponded to the water in interaction with particles and the water in the reconstituted phase. When mixing was stopped, the mixture underwent rapid sedimentation and the two relaxation components could be attributed to the sedimentation phase and the supernatant phase, respectively. This precipitate probably resulted from aggregation of casein micelles or submicelles through a decreasingly negative charge on the protein by additional $\mathrm{Ca}$ binding, leading to a reduction in electrostatic repulsion [2]. In this case, the high ISI of these solutions was related to the presence of insoluble substances, whereas in the case of rehydration of MC powder, the high ISI only represented the low water transfer rate in casein (Tab. I).

The various applications of the NMR relaxometry presented in this paper show the ability of this non-invasive technique to deliver novel and useful information about the reconstitution process of milk powders, which could be close to industrial conditions. The insolubility index and NMR relaxometry gave compatible information on powder rehydration. However, a high ISI did not indicate if the powder could be totally reconstituted in water, even after a long reconstitution period, or if the powder contained insoluble substances. Though it was more time-consuming, the NMR method clearly differentiated between the two phenomena. The method was able to measure long reconstitution periods in solutions where water transfers were slow and to detect the presence of insoluble structures in other solutions where rehydration was only partial. Moreover, a decrease in the transverse NMR relaxation rate of the reconstituted solution indicated greater and smaller changes in the micellar structures, resulting from the effects of certain additives on protein-protein interactions.

\section{TURBIDIMETRY, VISCOSIMETRY AND GRANULOMETRY}

The aims of this approach of the study were to acquire a greater understanding of the rehydration properties of high-protein milk powders such us micellar casein (MC) and whey protein isolates (WPI). Turbidity, granulometry and viscosimetry profiles were used to evaluate overall the rehydration properties of the powders in terms of wetting time, swelling time and rehydration time (solubility and dispersibility). The influences of protein powder type and particle size were evaluated in relation to rehydration properties $[10,11]$.

A Stress Tech Rheometer was used to obtain viscosity profiles. This apparatus was equipped with a custom-built paddle stirrer and a C25 cup. The paddle was constructed with four blades specially designed for large particles. The blades were placed at right angles to each other to provide good homogenization. Dissolution processes in the industry usually include stirring at a constant speed and the experiments were therefore determined for a 
constant shear rate $\left(100 \mathrm{~s}^{-1}\right)$. MC powder was added to the rheometer cup manually. The aqueous phase was distilled water, used at a volume of $18 \mathrm{~mL}$. The powder was dispersed in the rheometer cup, $50 \mathrm{~s}$ after starting the rheometer. Dissolution is highly dependent on temperature and concentration. The total nitrogen concentration employed to study these effects was close to $5 \%(\mathrm{w} / \mathrm{v})$ and the temperature was close to $24{ }^{\circ} \mathrm{C}[10,11]$.

For the turbidity profiles, the experiments were carried out in a 2 -L vessel equipped with a 4-blade $45^{\circ}$ impeller ( $\mathrm{R} 100$ impeller: 8-cm diameter) rotating at $400 \mathrm{rpm}$. The temperature was kept constant at $24{ }^{\circ} \mathrm{C}$ using a double-walled jacket vessel. The turbidity sensor was placed $3 \mathrm{~cm}$ below the water surface and positioned through the vessel wall to avoid disturbance during stirring. Turbidity changes accompanying powder rehydration were followed using a turbidity meter (Analite NEP 160, McVan Instruments, Mulgrave, Australia). This apparatus used light in the near-infrared region $(860 \mathrm{~nm})$, the incident beam being reflected back at $180^{\circ}$ by any particle in suspension in the fluid to a sensitive electronic receptor [10].

Particle size distributions were measured by a laser light diffraction apparatus (Mastersizer S, Malvern Instruments Ltd, Malvern, UK) with a 5-mW He-Ne laser operating at a wavelength of $632.8 \mathrm{~nm}$. Particle size distribution of dried particles was determined using a dry powder feeder attachment, and the standard optical model presentation for particles dispersed in air was used. For the particle size distribution of micellar casein in concentrate, $0.5 \mathrm{~mL}$ of $\mathrm{MC}$ suspension were taken from the rheometer cup and introduced into $100 \mathrm{~mL}$ of pre-filtered distilled water (membrane diameter $0.22 \mu \mathrm{m}$ ) to reach the correct obscuration. The results obtained were average diameters calculated from the Mie theory. The criterion selected was $\mathrm{d}(50)$, meaning that $50 \%$ of the particles had a diameter lower than this criterion (midpoint of cumulative volume distribution) $[10,11]$.

The use of turbidimetry, viscosimetry and granulometry to follow MC rehydration continuously was validated. Interpretation of the turbidity and viscosity coupled with static light scattering seems to be a promising tool to appreciate casein powder rehydration with parameters such as wetting time, swelling time and rehydration time (Tab. I). The wetting time is determined in relation to the first peak of increase in viscosity and turbidity. The wetting stage was followed by a swelling of the particles corresponding to a second peak in viscosity and an increase in particle size. The rehydration time is determined with the viscosity, turbidity and particle size stabilizations.

Wetting time was systematically better for granulate particles. Indeed, fast wetting is enhanced with large particles forming large pores, high porosity and a small contact angle between the powder surface and the penetrating water. Certain authors have reported an optimal size for wettability of around $400 \mu \mathrm{m}$, close to the size of the granulate powders used in this study [8]. The wetting stage is often described in the literature as a rate-controlling step [18]. In contrast, the dispersion stage seemed to be the rate-controlling step in this study. Indeed, even with a shorter wetting time, a granulate powder was slower to rehydrate than a non-granulate powder, but only for MC powders $[10,11]$. The time for these powders to rehydrate fully was largely influenced by granulation, as granulation was shown systematically to slow down the rehydration process. Granulate particles penetrated the water quickly but then dispersed slowly, whereas non-granulate particles presented poor wettability (powder floated on the water surface) but then dispersed more quickly.

The experiments reported here showed clearly that ultrafiltrate incorporation in 
the MC concentrate before spray-drying improved the rehydration time, and that the incorporation mode and granulation were significant. The rehydration time was improved when the carbohydrates or mineral salts (by adding ultrafiltrate) were added to the concentrate before spray-drying and were localized inside the powder particle compared with during or after in a dry mix. On the other hand, preferential localization of these molecules on the particle surface reduced the wetting time.

Recent studies have shown that the limiting factor for MC powder is rehydration (solubility and dispersibility), whereas for WPI powder, it is the wettability. To improve the wettability time of WPI powder, it is thus better to increase particle size, and to improve the rehydration time of a MC powder, it is better to decrease particle size $[3,9-11,19,20]$.

\section{CONCLUSIONS}

The IDF method, NMR spectroscopy, turbidimetry, viscosimetry and granulometry provide valuable information regarding the mechanisms involved during MC dissolution with constant stirring. The major results are reported in Table I.

Enrichment of milk in micellar casein decreased water transfer at the end of drying and during rehydration. Insolubility [15] was related to decrease in the water transfer needed for rehydration and not to thermal denaturation, and the decrease in water transfer was related to the micelle structure. The destructuration of micelle induced by addition of phosphate or citrate solution to MC increased water transfer during drying and during rehydration. The water transfer during rehydration of WPI and MC with added carbohydrates was greater than that of MC. Increased hygroscopicity of carbohydrates or $\mathrm{NaCl}$ improved water transfer during drying and during rehydration.
Water transfer in dairy protein concentrates during dehydration and rehydration was shown to be related to the aqueous environment, the nature of the mineral salts and the structure of dairy proteins (MC and WPI). Analysis of the turbidity, viscosity and particle size profile seems a promising tool to understand powder dissolution stages. We showed that temperature, concentration and time were the major factors influencing MC dissolution. It is also possible to improve the dissolution of MC powder by changing the chemical composition or the method of manufacture, these factors being closely connected with the physical structure of the powder.

Acknowledgements: The authors are indebted to ARILAIT RECHERCHES for stimulating discussions and financial support.

\section{REFERENCES}

[1] Baldwin A.J., Sanderson W.B., Factors affecting the reconstitution properties of whole milk powder, N. Z. J. Dairy Sci. Technol. 8 (1973) 92-100.

[2] Dalgleish D.G., Milk proteins. Chemistry and physics, in: Fox P.F., Condon J.J. (Eds.), Food proteins, Applied Sciences Publisher, London, UK, 1982, pp. 155-178.

[3] Davenel A., Schuck P., Marchal P., A NMR relaxometry method for determining the reconstituability and the water-holding capacity of protein-rich milk powders, Milchwissenschaft 52 (1997) 35-39.

[4] Davenel A., Schuck P., Mariette F., Brulé G., NMR relaxometry as a non-invasive tool to characterize milk powders, Lait 82 (2002) 465-473.

[5] Famelart M.H., Le Graet Y., Raulot K., Casein micelle dispersions into water, $\mathrm{NaCl}$ and $\mathrm{CaCl}_{2}$ : physicochemical characteristics of micelles and rennet coagulation, Int. Dairy J. 9 (1999) 293-297.

[6] Fauquant J., Maubois J.-L., Pierre A., Microfiltration du lait sur membrane minérale, Tech. Lait 1028 (1988) 21-23.

[7] Fitzpatrick J.J., Weidendorfer K., Weber M., Teunou E., Practical considerations for reconstituting dairy powders to high solids 
content in a stirred-tank, Milchwissenschaft 56 (2001) 512-516.

[8] Freudig B., Hogekamp S., Schubert H., Dispersion of powders in liquid in a stirred vessel, Chem. Eng. Proc. 38 (1999) 525-532.

[9] Gaiani C., Étude des mécanismes de réhydratation des poudres laitières: Influence de la structure et de la composition des poudres, Ph.D. thesis INPL, ENSAIA, Nancy, France, 2006.

[10] Gaiani C., Banon S., Scher J., Schuck P., Hardy J., Use of a turbidity sensor to characterize casein powders rehydration: influence of some technological effects, J. Dairy Sci. 88 (2006) 2700-2706.

[11] Gaiani C., Scher J., Schuck P., Hardy J., Desobry S., Banon S., The dissolution behaviour of native phosphocaseinate as a function of concentration and temperature using a rheological approach, Int. Dairy J. 16 (2006) 1427-1434.

[12] I.D.F., Détermination de l'indice d'insolubilité. Standard 129A, Int. Dairy Fed., Brussel, Belgium, 1988.

[13] Jost R., Functional characteristics of dairy proteins, Trends Food Sci. Technol. 4 (1993) 283-288.

[14] King N., Dispersibility and reconstitutability of dried milk, Dairy Sci. Abs. 28 (1966) 105118.

[15] Mora-Gutierrez A., Farrell H.M. Jr., Kumosinski T.F., Comparison of hydration of bovine and caprine caseins as determined by oxygen-17 nuclear magnetic resonance: effects of salt, J. Agric. Food Chem. 43 (1995) 2474-2579.

[16] Pierre A., Fauquant J., Le Graet Y., Piot M., Maubois J.-L., Préparation de phosphocaséinate natif par microfiltration sur membrane, Lait 72 (1992) 461-474.

[17] Pisecky J., Handbook of milk powder manufacture, Niro A/S (Ed.), Copenhaguen, Denmark, 1997.

[18] Schubert H., Instantanization of powdered food products, Int. Chem. Eng. 33 (1993) 28-45.

[19] Schuck P., Piot P., Méjean S., Fauquant J., Brulé G., Maubois J.-L., Déshydratation par atomisation de phophocaséinate natif obtenu par microfiltration sur membrane, Lait 74 (1994) 375-388.

[20] Schuck P., Roignant M., Brulé G., Davenel A., Famelart M.H., Maubois J.-L., Simulation of water transfer in spray drying, Drying Technol. 16 (1998) 1371-1393.

[21] Schuck P., Davenel A., Mariette F., Briard V., Méjean S., Piot M., Rehydration of casein powders: effects of added mineral salts and salt addition methods on water transfer, Int. Dairy J. 12 (2002) 51-57.

[22] Straatsma J., Van Houwelingen G., Steenbergen A.E., De Jong P., Spray drying of food products: 2. Prediction of insolubility index, J. Food Eng. 42 (1999) 73-77. 